\title{
Local Cultivars of Sweet Potato in West Sumatra, Indonesia: Its Characteristics, Yield Potentials, and Organoleptic Values
}

\author{
Zul Irfan ${ }^{1,{ }^{*}}$ Sumilah $^{1}$ Srimaryati $^{1}$
}

\author{
${ }^{1}$ West Sumatra Assessment Institute for Agricultural Technology, Sukarami 27365, Indonesia \\ *Corresponding author. Email: irfanchan@yahoo.com
}

\begin{abstract}
Sweet potato is one of the major food crops in Indonesia. More than 20 national varieties of sweet potato have been released by the Indonesian government since 1977. However, most of farmers in West Sumatra province have not used national varieties, but they consistently planted local varieties. Researches with the objectives of to overcome the characteristics, yield potentials, and organoleptic values of local cultivars of sweet potato in West Sumatra have been done in the period of 2016-2017. Researches were started with the exploration of sweet potato's local cultivars of West Sumatra, continued with the characterization, testing of its yield potentials, and evaluating its organoleptic values. Exploration was done in Agam, Tanah Datar, and Solok regencies, the three central regions of sweet potato farming in West Sumatra. Characterization of the above sweet potato's local cultivars was done at the Sukarami experimental farm of West Sumatra Assessment Institute for Agricultural Technology. An experiment for yield potential testing was conducted at the farmer's field of Gunung Talang district, Solok regency. Organoleptic test was done involving farmers and extension workers as the panelists. Two national varieties of sweet potato, namely Antin-3 and Papua Solossa, were used as the control in the yield potential and organoleptic testings. Results showed that there were eight local cultivars of sweet potato planted mostly in West Sumatra, i.e. Daus, Pono, Wali and Bogor in Agam regency; Hitam Pucuk Panyalaian in Tanah Datar regency; and Wortel, Roti and Rajo Langik in Solok regency. These local cultivars have different characteristics in term of its growth performance, stems, leaves, and tubers. Two local cultivars, i.e. Rajo Langik and Wali, produced significantly higher yield (56.45 t/ha and $47.94 \mathrm{t} / \mathrm{ha})$ than the national varieties Antin-3 (25.39 t/ha) and Papua Solossa (34.33 t/ha). All local cultivars tested produced significantly higher yield than Antin-3. Appearance, flavour, texture, color, and sweetness of boiled storage roots of all local cultivars of sweet potato in West Sumatra were not inferior to and even the local cultivar Daus better than the national varieties Antin-3 and Papua Solossa.
\end{abstract}

Keywords: Sweet potato, local cultivars, characteristics, yield potential, organoleptic

\section{INTRODUCTION}

Sweet potato (Ipomoea batatas) is one of the most important food crops in Indonesia as well as in tropical and subtropical regions in the world as mentioned by Tanaka et al. [17]. Regarding to the importance of sweet potato, Woolfe [13] mentioned that this commodity was an important nutrition source especially in developing countries because the storage roots of sweet potato were rich in vitamins and minerals, and also contained a large amount of starch. Based on the sweet potato's coverage area and production, Indonesia is the forth country in the world after China, Vietnam, and Uganda. In this country, sweet potatoes are cultivated in an array of agro-ecological zones, ranging from the low elevation to high elevation areas higher than 3,000 $\mathrm{m}$ above sea level. Suryani [21] stated that West Sumatra was the fifth province in term of coverage area and production of sweet potato in Indonesia. As assumed by Mok and Schmiediche [10], a large amount of sweet potato's genetic diversity are existence on the Indonesian archipelago.

Jusuf et al. [15] stated that most sweet potato farmers in Indonesia used hundreds of local cultivars planted in different environments. It means that the farmers in different regions planted different local cultivars. According to Jusuf et al. [15], the farmers in Java grow one or two of the most popular cultivars in large areas. They also mentioned the different fact in Papua where the farmers usually grow a large number of cultivars in a particular field. Farmers use local cultivars of sweet potato which are well adapted to the 
specific soil and climatic conditions. The South Sumatra province, for instance, has local cultivars of sweet potato which are resistance to drought and potential to be planted in marginal land. West Sumatra province has also some local cultivars of sweet potato which are generally planted by the farmers in its central regions.

Regarding to the importance of crops local germplasms or local cultivars for sweet potato, an Indonesian environmentalist, Salim [6] reminded that we have to give more attention to save or conserve and utilize wisely mega biodiversities in Indonesia. He mentioned examples of some nations which have made their state icons using their local germplasms showing how they seriously conserved their genetic resources, like Tulip flower in Netherlands, Sakura in Japan, and Ginseng in the South Korea. Indonesia is a rich nation in term of local germplasms which has various flora and fauna. The diversity of local germplasms is important as the material genetics for breeding and provides economical benefits for the nation. Therefore, identification, characterization, as well as documentation of local germplasms are urged to be done by researchers and others.

According to Yakub et al. [16], Indonesia is even considered to be a secondary center of genetic diversity of sweet potato. Local cultivars serve as a source of genetic variabilities, it could be used as gene donors in the variety improvement programs. Therefore, collection and conservation of sweet potato germplasms are very important in order to maintain the full range of genetic variability within the species.

As many as 24 popular varieties of sweet potato have been released by the Indonesian government since 1977 up to 2017 [11]. However, most of farmers in the sweet potato's central regions, including in West Sumatra province, still consistently use local cultivars. These local cultivars may have specific superiority compared to popular national varieties. Therefore, enough information about local cultivars of sweet potato which are planted most by the farmers in different regions is important, particularly in term of its: (1) characteristics, (2) yield potentials, and (3) organoleptic values or characteristics of its storage roots. The series of these researches attempted to overcome the characteristics, yield potentials, and organoleptic values of local cultivars of sweet potato in West Sumatra province, Indonesia.

\subsection{Related Work}

Related to the sweet potato local cultivars, we divided the existed work into three categories, which are sweet potato breeding, the importance of local cultivars, and yield potentials of sweet potato.

\subsubsection{Sweet potato breeding}

Regarding the sweet potato bereeding, Tanaka et al. [17] stated that the traditional breeding schemes is still important and can be incorporated with newly developed genetic tools for sweet potato breeding programs. Whereas, El Gendy and Khalik [3] mentioned that the phenotypic recurrent selection was found to be more effective in improving local varieties of sweet potato.

Oggema et al. [14] compared growth and yield characteristics between tissue culture regenerated and conventionally propagated five locally adapted sweet potato cultivars. They found that conventional propagation method gave the highest growth rates, however the difference in yield between the conventional propagation and tissue culture regenerated plants did not vary significantly. Moreover, Dewi et al. [20] explained that the sweet potato characters like weight of large storage roots, number of large storage roots, storage root length, storage root diameter, vines length, segment length, vines diameter, and weight of vines had a value of genetic diversity. The germplasm of 30 sweet potato genotypes found in Lampung could be selected and crossed to create the desired superior characters.

Kosmowski et al. [7] presented the results of a data capture experiment on sweet potato varietal identification in southern Ethiopia. In total, $20 \%$ of farmers identified a variety as improved when in fact it was local and $19 \%$ identified a variety as local when it was in fact improved. Samiyarsih et al. [25] has conducted a research regarding to genetic variability of sweet potato cultivars in Banyumas, Central Java. They stated that results of their investigations would be mainly used for identification and useful for the evaluation of the genetic improvement of sweet potato cultivars.

\subsubsection{The importance of local cultivars}

Laurie et al. [24] charaterized 51 sweet potato South African landraces and six local cultivars. The study provided information concerning locally available sweet potato germplasm and is of vital importance for advancement in the sweet potato improvement program in South Africa. In West Cameroon, on the other hand, traditional varieties of sweet potato are less productive in the range of 3 to 5 tons per hectare compared with 5 to 10 tons per hectare in the improved varieties [2].

In Bayelsa State, Nigeria, the improved varieties of sweet potato produced higher root yields [5] Identification of 35 local cultivars of sweet potato in the Faculty of Agriculture, Padjadjaran University, Indonesia showed that there were a diversity from morphological appearance of sweet potatoes landraces from Cilembu village [23]. 


\subsubsection{Yield potentials of sweet potato}

Laurie et al. [22] have conducted 15 on farm trials to evaluate seven sweet potato cultivars in South Africa across the 2011/12 to 2014/15 planting seasons. Data collection included marketable and unmarketable storage roots and taste acceptability. They found that the marketable yield of cultivars tested ranged from 13.1 to $19.0 \mathrm{t} / \mathrm{ha}$ and the mean of marketable yield was 15.8 t/ha. Oggema et al. [14] stated that the difference in number of tubers produced and sub-sequent yield across the treatments was probably due to variation among the cultivars, their maturity and their response to the external environment.

\subsection{Our Contribution}

Information about local cultivars of sweet potato which are planted most by the farmers is important, especially on its productivity for fresh marketing and organoleptic values for storage roots processing. This paper presents the researches results on the exploration and identification, yield potential testing, and organoleptic values or consumer acceptance to eight local cultivars of sweet potato in West Sumatra, Indonesia. Considering to the importance of sweet potato germplasms, we reveal that local cultivars of sweet potato in West Sumatra have a prominent potency to be parent materials for sweet potato breedings and even to increase its status to be the national varieties of sweet potato in Indonesia. This paper also reveals the characteristics of local cultivars of sweet potato in West Sumatra.

\subsection{Paper Structure}

The rest of the paper is organized as follows. Section 2 contains the research methodology, which includes the activities of exploration, morphological characterization, yield potential testing, and consumers' acceptance test on the storage roots of sweet potato local cultivars. Section 3 presents the data and discussion of research results, which includes morphological characteristics of sweet potato local cultivars, its yield potentials compared to the national checked varieties, and consumers' likings to boiled storage roots of local cultivars and national checked varieties. Finally, Section 4 concludes the paper and presents direction for future researches.

\section{MATERIALS AND METHODS}

Researches to overcome the characteristics, yield potentials, and organoleptic values of local cultivars of sweet potato have been done in West Sumatra province, Indonesia in 2016-2017. The research coverage included: exploration, characterization, yield potential testing, and organoleptic test of boiled tubers of the sweet potato's local cultivars of West Sumatra.

\subsection{Exploration}

Exploration of sweet potato's local cultivars of West Sumatra was done in Agam, Tanah Datar, and Solok regencies, the three central areas of sweet potato in the province in 2016. The regions for exploration covered three districts in Agam regency (Ampek Angkek, Baso and Canduang), one district in Tanah Datar regency (Pariangan), and two districts in Solok regency (Gunung Talang and Lembang Jaya). All locations are located on high elevation areas with altitude ranged from 700 to $1200 \mathrm{~m}$ above sea level. The soil types of the sweet potato's planted area in Agam regency are Entisols, Inceptisols and Ultisols; in Tanah Datar regency is Andosols; and in Solok regency are Inceptisols and Andosols (Figure 1).

During the exploration activity, all local cultivars of sweet potato generally planted by the farmers were collected. As many as 50 sprouts of each variety were taken out and brought to the West Sumatra Assessment Institute for Agricultural Technology.

\subsection{Morphological characterization}

Morphological characterization of the sweet potato's local cultivars of West Sumatra was done at the Sukarami experimental farm of West Sumatra Assessment Institute for Agricultural Technology. For morphological characterization, each cultivar was planted in three mounds with a size of $1 \mathrm{~m} \mathrm{x} 3 \mathrm{~m}$, one cutting per planting hole. The planting distance was 100 $\mathrm{cm} \times 25 \mathrm{~cm}$, so that one roll had 12 plants and there were 36 plants for each cultivar. The crops were fertilized with organic (manure) and inorganic fertilizers. Manure was applied above the mounds one day before planting. Plants were fertilized with $150 \mathrm{~kg}$ Urea, $100 \mathrm{~kg} \mathrm{SP36}$, and $100 \mathrm{~kg} \mathrm{KCl}$ per hectare. Two-third part of Urea, $100 \%$ of SP36 and $50 \%$ of $\mathrm{KCl}$ were applied at planting time, and the other $1 / 3$ of Urea and $50 \%$ of $\mathrm{KCl}$ were applied 1.5 months after planting. 

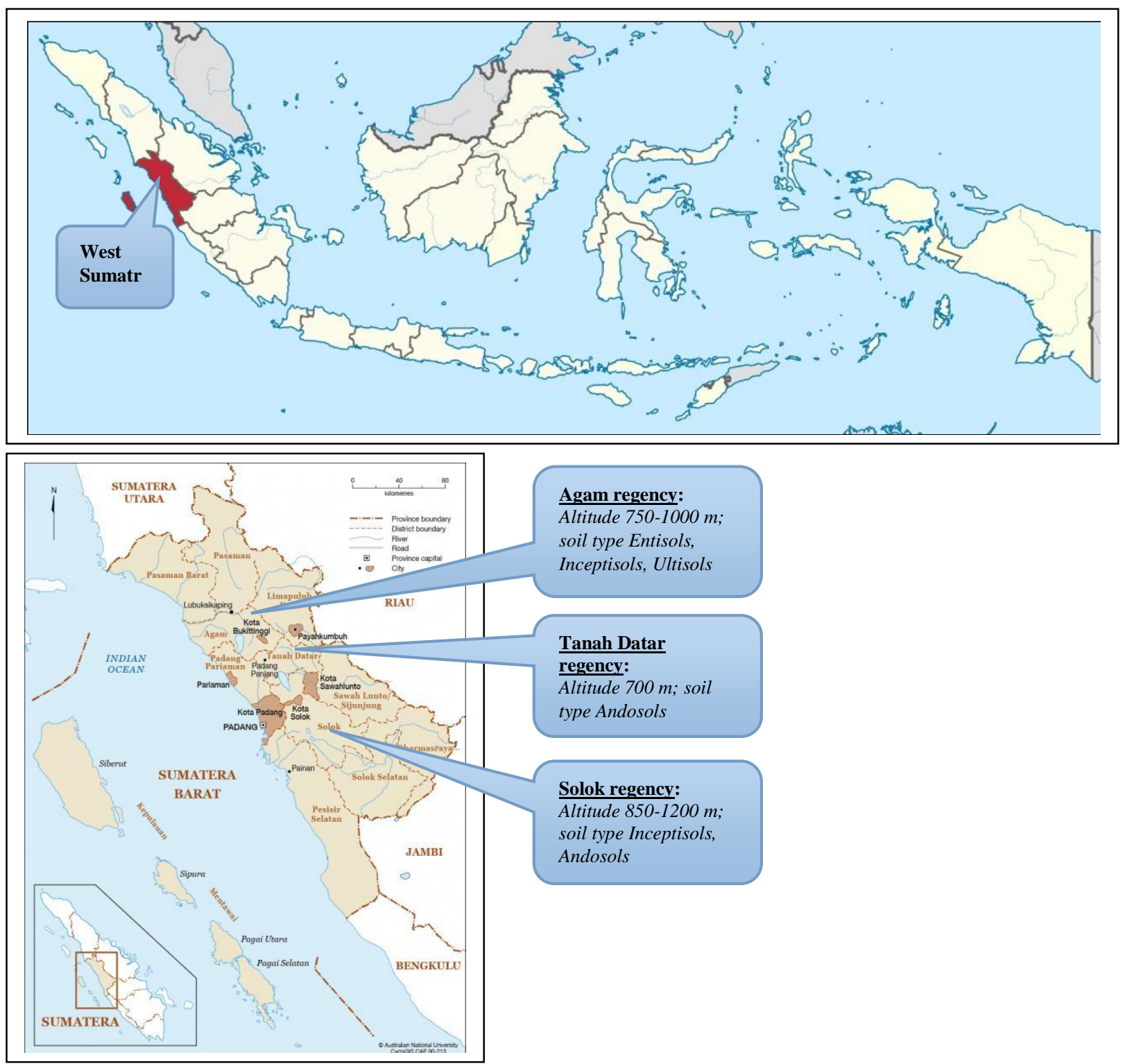

Figure 1 The map of Indonesia directed West Sumatra province (upper) and the map of West Sumatra and the regencies where local cultivars of sweet potato were colected (under).

Hand weedings were done two times, one and two months after planting. Each cultivar was characterized in terms of its growth performance, stems, leaves, and storage roots.

\subsection{Yield potential testing}

The experiment was carried out in a farmer's field of Koto Gadang Guguk village (about $870 \mathrm{~m}$ above sea level), Gunung Talang district, Solok regency. The experiment used eight sweet potato's local cultivars of West Sumatra collected during exploration and two national popular varieties as the check (Table 1). Each cultivar was planted in a plot which consisted four mounds with a size of $1 \mathrm{~m} \times 5 \mathrm{~m}$, one cutting per planting hole. The planting distance was $100 \mathrm{~cm}$ x 25 $\mathrm{cm}$, so that one roll had 20 plants or 80 plants per plot. The experimental used was a randomized block design with three replications. 
Table 1 List of local cultivars and national varieties of sweet potato tested in this study.

\begin{tabular}{|l|l|l|}
\hline Cultivars & Explanation & Place of origin \\
\hline Bogor & Agam's local & Baso district \\
\hline Daus & Agam's local & Canduang district \\
\hline Pono & Agam's local & Ampek Angkek district \\
\hline Wali & Agam's local & Ampek Angkek district \\
\hline Hitam Pucuk Panyalaian & Tanah Datar's local & Pariangan district \\
\hline Rajo Langik & Solok's local & Gunung Talang district \\
\hline Roti & Solok's local & Lembang Jaya district \\
\hline Wortel & Solok's local & Gunung Talang district \\
\hline Antin-3 & National variety & ILETRI, Malang \\
\hline Papua Solossa & National variety & ILETRI, Malang \\
\hline
\end{tabular}

The plants were fertilized with organic (manure) and inorganic fertilizers. Manure with a dose of 2 tons per hectare was applied above the mounds one day before planting. Plants were fertilized with $150 \mathrm{~kg}$ Urea, $100 \mathrm{~kg} \mathrm{SP} 36$, and $100 \mathrm{~kg} \mathrm{KCl}$ per hectare. One-third part of Urea, $100 \%$ of SP36 and $50 \%$ of $\mathrm{KCl}$ were applied at planting time, and $2 / 3$ part of Urea and $1 / 2$ part of $\mathrm{KCl}$ were applied 1.5 months after planting. Hand weeding was done two times, one and two months after planting. The sweet potato crops were harvested four months after planting. Observations were done at harvesting time. The characters observed were the storage root shapes, storage root skin colors, flesh colors, number and weight of storage roots $/ 6 \mathrm{~m}^{2}$, number and weight of marketable storage roots $/ 6 \mathrm{~m}^{2}$, number and weight of nonmarketable storage roots $/ 6 \mathrm{~m}^{2}$, yield per hectare.

\subsection{Organoleptic test of storage roots}

Organoleptic values was assessed through consumers acceptance on the boiled storage roots of all sweet potato local cultivars tested and two checked national varieties right after being harvested. In this test, some storage roots per cultivars and varieties were taken from experimental field, place in bags, and identified with symbols (numbers) written on identification tags in felt-tipped marker. The roots were then cooked, so that the panelists could taste small pieces of each one. Their assessment was recorded. After the participants have tasted one clone, they took a sip of water, so that they had less trouble making a distinction between the taste of that cultivar or variety and the next. Organoleptic assessment involved 12 semi trained farmers and 3 extension workers as the panelists. The sensory atributes evaluated were its appearance, flavour, color, texture, and sweetness of boiled storage roots using hedonic scales 1 to 5 adopted from Badiane et al. (2018) and Leksrisompong et al. (2012), where 5 was anchored with "like extremely" and 1 was anchored with "dislike extremely".

Table 2 Types of growth, stem colors, dominant and secondary colors of vines of the eight sweet potato's local cultivars in West Sumatra province, Indonesia.

\begin{tabular}{|l|c|c|c|c|}
\hline \multirow{2}{*}{ Cultivars } & \multirow{2}{*}{ Types of growth } & \multirow{2}{*}{ Stem colors } & \multicolumn{2}{c|}{ Color of vines } \\
\cline { 3 - 5 } & & & Dominant & Secondary \\
\hline Bogor & semi-compact & light green & green & purple \\
\hline Daus & compact & light green & green & purple \\
\hline Hitam Pucuk Panyalaian & semi-compact & green & green & purple \\
\hline Pono & semi-compact & green-purple & purple & light green \\
\hline Rajo Langik & semi-compact & green & green & purple \\
\hline Roti & compact & brownish green & green & purple \\
\hline Wali & compact & green-purple & green & purple \\
\hline Wortel & semi-compact & purple & purple & light green \\
\hline
\end{tabular}




\section{RESULTS AND DISCUSSION}

\subsection{Characteristics of Sweet Potato Local Cultivars}

Eight local cultivars of sweet potato have been collected during the exploration activity in the three regencies in West Sumatra. Four cultivars namely Bogor, Daus, Pono, and Wali were found in Agam regency; one cultivar namely Hitam Pucuk Panyalaian was collected in Tanah Datar regency; and three cultivars namely Rajo Langik, Roti, and Wortel were collected in Solok regency. Morphological characterization was done to all of these cultivars following the guidance which was developed by Huaman [28]. Kamalkumaran and Arumugam [19] stated that morphological characterization was an important first step in the assessment of sweet potato diversity.

Results showed that there was a difference among eight sweet potato's local cultivars of West Sumatra in each observed character (Table 2, 3 and 4). Three (37.5\%) of them had erect or compact and $62.5 \%$ had semi-compact types of growth. The colors of the sweet potato local cultivars' stems and vines were also different. Two cultivars had light green, two cultivars had green, and two cultivars had green purple stem colors. Only one cultivar had purple (Wortel) and brownish green (Roti) stem color. The dominant and secondary colors of its vines are mostly green and purple, $75 \%$ and $75 \%$ respectively. Only $25 \%$ of them had purple dominant color of vines and light green secondary color (Table 2).
Huaman [27] mentioned that the types of growth habit of sweet potato cultivars were erect or compact, semi-compact, spreading, and very spreading. He also stated that the stem color varied from green to totally pigmented with anthocyanins (red-purple color), the dominant color of vines varied from green to totally dark purple, and the secondary color of vines varied from absent to purple [28]. For the observed sweet potato's local cultivars of West Sumatra, semi-compact type of growth, green dominant color of vines, and purple secondary color of vines, were more dominant. These facts illustrated the types of growth of the sweet potato cultivars in Indonesia in general. An institution mandated to do research on tuber crops, ILETRI [12] informed that from its 331 collected accessions, $38.1 \%$ of sweet potato cultivars had semi-compact type of growth, $45.32 \%$ had green dominant color of vines, and $34.74 \%$ had purple secondary color of vines especially on its nodes.

Seven characters of sweet potato leaves were observed in this research, i.e. length and color of petiole, shape and size of mature leaves, and color of mature leaves, immature leaves and veins of leaves. Results of observation showed that the petioles of the sweet potato's local cultivars of West Sumatra ranged from very short ( 3 cultivars) to intermediate ( 1 cultivar). The other 4 cultivars had short petiole (Table 3). Categorization was made based on the standard developed by Huaman [28]. The color of petiole which was named by Huaman [28] as petiole pigmentation varied among observed cultivars, 3 cultivars had green, 2 cultivars had purple, 2 cultivars has green-purple, and 1 cultivar had light green petioles. All cultivars varied in term of its shape and size of mature leaves.

Table 3 The characteristics of leaves of the eight sweet potato's local cultivars in West Sumatra.

\begin{tabular}{|c|c|c|c|c|c|c|c|}
\hline \multirow[b]{2}{*}{ Cultivars } & \multirow{2}{*}{$\begin{array}{l}\text { Length of } \\
\text { petiole }\end{array}$} & \multirow[b]{2}{*}{$\begin{array}{c}\text { Color of } \\
\text { petiole }\end{array}$} & \multirow{2}{*}{$\begin{array}{c}\text { Shape of } \\
\text { mature } \\
\text { leaves }\end{array}$} & \multirow{2}{*}{$\begin{array}{c}\text { Size of } \\
\text { mature } \\
\text { leaves }\end{array}$} & \multicolumn{3}{|c|}{ Color of } \\
\hline & & & & & $\begin{array}{c}\text { Mature } \\
\text { leaves }\end{array}$ & $\begin{array}{c}\text { Immature } \\
\text { leaves }\end{array}$ & $\begin{array}{l}\begin{array}{l}\text { Veins of } \\
\text { leaves }\end{array} \\
\end{array}$ \\
\hline Bogor & $\begin{array}{c}17-23 \mathrm{~cm} \\
\text { (intermediate) }\end{array}$ & light green & cordate & wide & $\begin{array}{l}\text { dark } \\
\text { green }\end{array}$ & light green & green \\
\hline Daus & $\begin{array}{l}11-19 \mathrm{~cm} \\
\text { (short) }\end{array}$ & $\begin{array}{l}\text { green- } \\
\text { purple }\end{array}$ & hastate & medium & $\begin{array}{l}\text { dark } \\
\text { green }\end{array}$ & green & purple \\
\hline $\begin{array}{l}\text { Hitam Pucuk } \\
\text { Panyalaian }\end{array}$ & $\begin{array}{c}5-7 \mathrm{~cm} \\
\text { (very short) }\end{array}$ & $\begin{array}{l}\text { green- } \\
\text { purple }\end{array}$ & $\begin{array}{l}\text { slight } \\
\text { lobed }\end{array}$ & wide & $\begin{array}{l}\text { dark } \\
\text { green }\end{array}$ & purple & purple \\
\hline Pono & $\begin{array}{c}12-17 \mathrm{~cm} \\
\text { (short) }\end{array}$ & purple & divided & narrow & $\begin{array}{l}\text { dark } \\
\text { green }\end{array}$ & $\begin{array}{l}\text { green- } \\
\text { purple }\end{array}$ & green \\
\hline Rajo Langik & $9-12 \mathrm{~cm}$ (short) & green & $\begin{array}{l}\text { slight } \\
\text { lobed }\end{array}$ & medium & green & purple & $\begin{array}{l}\text { green- } \\
\text { purple }\end{array}$ \\
\hline Roti & $8-14 \mathrm{~cm}$ (short) & green & $\begin{array}{l}\text { slight } \\
\text { lobed }\end{array}$ & wide & $\begin{array}{l}\text { dark } \\
\text { green }\end{array}$ & light green & green \\
\hline Wali & $\begin{array}{c}7-11 \mathrm{~cm} \\
\text { (very short) }\end{array}$ & green & five lobed & medium & green & purple & green \\
\hline Wortel & $\begin{array}{c}5-10 \mathrm{~cm} \text { (very } \\
\text { short) }\end{array}$ & purple & five lobed & medium & $\begin{array}{l}\text { dark } \\
\text { green }\end{array}$ & purple & purple \\
\hline
\end{tabular}


In the case of storage roots, Huaman [27] explained that the storage roots of sweet potato varied in shape and size according to the cultivar. The shape could be round, round-elliptic, elliptic, ovate, obovate, oblong, long oblong, long elliptic, and long irregular or curved. The storage root skin color could be whitish, cream, yellow, orange, brown-orange, pink, red-purple, and very dark purple. The flesh color could be white, cream, yellow, or orange.

Results of observation (Table 4) showed that there was a difference regarding to the storage root characteristics among the sweet potato's local cultivars in West Sumatra province, Indonesia. Three of the collected local cultivars had elliptic, three of its had round elliptic, one had long elliptic, and the other one had obovate storage root shapes. Moreover, the eight observed local cultivars of sweet potato in West Sumatra province, Indonesia were divided into three colors of storage roots skin, i.e. whitish (Bogor, Daus, Hitam Pucuk Panyalaian and Roti cultivars), cream (Pono and Rajo Langik cultivars), and orange (Wali and Wortel cultivars). The eight local cultivars also had three colors of its storage roots flesh, i.e. white (Bogor and Hitam Pucuk Panyalaian cultivars), cream (Daus, Pono and Roti cultivars), and orange (Rajo Langik, Wali and Wortel cultivars) (Table 4).

Table 4 The characteristics of storage roots of the eight sweet potato's local cultivars of West Sumatra, Indonesia.

\begin{tabular}{|l|c|c|c|}
\hline \multicolumn{1}{|c|}{ Cultivars } & $\begin{array}{c}\text { Storage root } \\
\text { shapes }\end{array}$ & $\begin{array}{c}\text { Storage root skin } \\
\text { colors }\end{array}$ & Flesh colors \\
\hline Bogor & Round elliptic & Whitish & White \\
\hline Daus & Elliptic & Whitish & Cream \\
\hline Hitam Pucuk Panyalaian & Elliptic & Whitish & White \\
\hline Pono & Elliptic & Cream & Cream \\
\hline Rajo Langik & Round elliptic & Cream & Orange \\
\hline Roti & Long elliptic & Whitish & Cream \\
\hline Wali & Round elliptic & Orange & Orange \\
\hline Wortel & Obovate & Orange & Orange \\
\hline
\end{tabular}

\subsection{Yield Potentials}

A local cultivar of sweet potato in West Sumatra province, Indonesia which is named Rajo Langik produced the highest yield (56.45 t/ha) in the yield potential testing. This cultivar was collected from Solok regency. The second highest yield (47.94 t/ha) was produced by local cultivar Wali collected from Agam regency. The yield of these two local cultivars is significantly higher than the yield of national improved varieties Papua Solossa and Antin-3, which were 34.33 t/ha and 25.39 t/ha, respectively (Figure 2). All local cultivars tested yielded more than $30 \mathrm{t} / \mathrm{ha}$, significantly higher than the average yield of sweet potato usually gained by the farmers at the same location (11.8 t/ha) and the average national sweet potato production in Indonesia (16.82 t/ha) [21]. The lowest yield of local cultivars was found in Roti (31.06 t/ha), lower than the yield of Papua Solossa but higher than the yield of Antin-3. Four local varieties (Rajo Langik, Wali, Wortel, and Pono) even produced higher yield than national variety Antin-2 which has the highest yield potential in Indonesia (37.1 t/ha) [11].

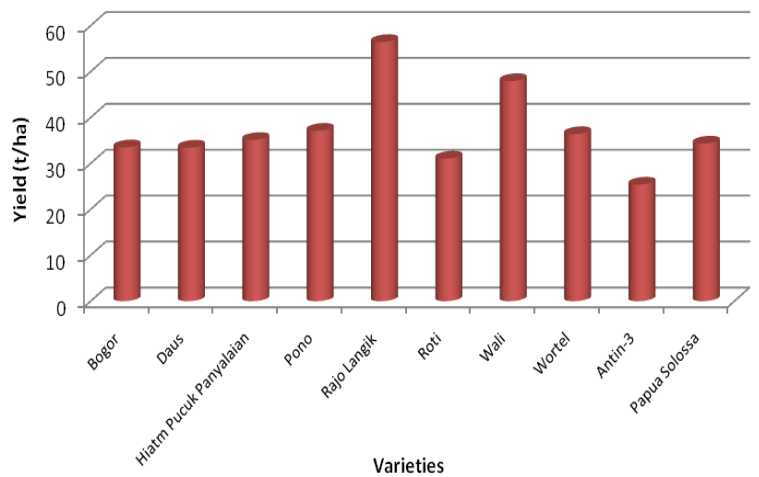

Figure 2 The yields of eight sweet potato local cultivars and two national improved varieties in Gunung Talang region, West Sumatra, Indonesia.

All local cultivars of sweet potato in West Sumatra which were tested in this research are potential to become introduced varieties in Indonesia and even in other countries, because all of its produce high yield. The yield of these local cultivars is even higher compared to the national average of sweet potato yield in Ethiopia (7.6 t/ha) [7], and yield of improved and traditional varieties in West-Cameroon which were 5 
to $10 \mathrm{t} / \mathrm{ha}$ and 3 to $5 \mathrm{t} / \mathrm{ha}$, respectively [2]. The yield of those local cultivars are also higher than orange flesh sweet potato CO 5 selected accession in India which produced 28.59 t/ha [19]. The selected accession of sweet potato $\mathrm{CO} 5$ has been released as a state variety in Tamilnadu, India.

The high yield or productivity of Rajo Langik and Wali local cultivars of West Sumatra are supported by high number of its marketable storage roots as well as weight of its storage roots and weight of its marketable storage roots (Table 5 and 6). Data in Table 5 showed that Rajo Langik local cultivar produced the highest number of marketable storage roots per $6 \mathrm{~m}^{2}$ and significantly different from other cultivars and two checked national varieties. Number of marketable storage roots per $6 \mathrm{~m}^{2}$ of Bogor and Wali local cultivars were significantly higher than that of the national variety Papua Solossa.

Table 5 Number of storage roots, marketable storage roots, non-marketable storage roots, and percentage of nonmarketable storage roots based on its number of eight sweet potato's local cultivars of West Sumatra and two national varieties.

\begin{tabular}{|c|c|c|c|c|}
\hline Cultivars/Varieties & $\begin{array}{l}\text { No. of storage } \\
\text { roots / } 6 \mathrm{~m}^{2}\end{array}$ & $\begin{array}{c}\text { No. of } \\
\text { marketable } \\
\text { storage roots / } \\
6 \text { m}^{2} \\
\end{array}$ & $\begin{array}{c}\text { No. of non- } \\
\text { marketable } \\
\text { storage roots / } \\
6 \text { m }^{2} \\
\end{array}$ & $\begin{array}{c}\text { Percentage of non- } \\
\text { marketable storage } \\
\text { roots based on its } \\
\text { number }\end{array}$ \\
\hline Bogor & $126.7 \mathrm{a}$ & $93.67 \mathrm{~b}$ & $33.00 \mathrm{a}$ & $26.25 \mathrm{a}$ \\
\hline Daus & $118.7 \mathrm{a}$ & $82.00 \mathrm{bc}$ & $36.67 \mathrm{a}$ & $30.98 \mathrm{a}$ \\
\hline Hitam Pucuk Panyalaian & $151.0 \mathrm{a}$ & 88.67 bc & $62.33 \mathrm{a}$ & $41.34 \mathrm{a}$ \\
\hline Pono & $129.3 \mathrm{a}$ & 82.67 bc & $46.67 \mathrm{a}$ & $35.56 \mathrm{a}$ \\
\hline Rajo Langik & $156.0 \mathrm{a}$ & $124.33 \mathrm{a}$ & $31.67 \mathrm{a}$ & $20.14 \mathrm{a}$ \\
\hline Roti & $141.0 \mathrm{a}$ & $89.33 \mathrm{bc}$ & $51.67 \mathrm{a}$ & $34.65 \mathrm{a}$ \\
\hline Wali & $124.0 \mathrm{a}$ & $95.67 \mathrm{~b}$ & $28.33 \mathrm{a}$ & $23.25 \mathrm{a}$ \\
\hline Wortel & $122.0 \mathrm{a}$ & $87.67 \mathrm{bc}$ & $34.33 \mathrm{a}$ & $27.79 \mathrm{a}$ \\
\hline Antin-3 & $100.3 \mathrm{a}$ & $68.00 \mathrm{bc}$ & $32.33 \mathrm{a}$ & $32.97 \mathrm{a}$ \\
\hline Papua Solossa & $107.0 \mathrm{a}$ & $60.67 \mathrm{c}$ & $46.33 \mathrm{a}$ & $43.10 \mathrm{a}$ \\
\hline $\mathrm{CV}(\%)$ & 15.90 & 17.02 & 38.08 & 28.64 \\
\hline
\end{tabular}

Data at the same column followed by the same characters are not significantly different according to DNMRT 5.0\%.

Table 6 Weight of storage roots, marketable storage roots, non-marketable storage roots, and percentage of nonmarketable storage roots based on its weight of eight sweet potato's local cultivars of West Sumatra and two national varieties.

\begin{tabular}{|c|c|c|c|c|}
\hline Cultivars/Varieties & $\begin{array}{c}\text { Weight of } \\
\text { storage roots } \\
/ 6 \mathrm{~m}^{2}\end{array}$ & $\begin{array}{c}\text { Weight of } \\
\text { marketable } \\
\text { storage roots / } \\
6 \text { m }^{2}\end{array}$ & $\begin{array}{c}\text { Weight of non- } \\
\text { marketable } \\
\text { storage roots / } \\
6 \text { m }^{2}\end{array}$ & $\begin{array}{c}\text { Percentage of } \\
\text { marketable storage } \\
\text { roots based on its } \\
\text { weight }\end{array}$ \\
\hline Bogor & $20.10 \mathrm{bc}$ & $18.60 \mathrm{~b}$ & $1.50 \mathrm{a}$ & $92.53 \mathrm{a}$ \\
\hline Daus & $20.07 \mathrm{bc}$ & $18.33 \mathrm{~b}$ & $1.73 \mathrm{a}$ & $91.18 \mathrm{a}$ \\
\hline Hitam Pucuk Panyalaian & $21.07 \mathrm{~b}$ & $18.07 \mathrm{~b}$ & $3.00 \mathrm{a}$ & $85.36 \mathrm{a}$ \\
\hline Pono & $22.27 \mathrm{~b}$ & $20.00 \mathrm{~b}$ & $2.27 \mathrm{a}$ & $89.37 \mathrm{a}$ \\
\hline Rajo Langik & $33.87 \mathrm{a}$ & $32.67 \mathrm{a}$ & $1.20 \mathrm{a}$ & $96.26 \mathrm{a}$ \\
\hline Roti & $18.63 \mathrm{bc}$ & $15.90 \mathrm{bc}$ & $2.73 \mathrm{a}$ & $85.73 \mathrm{a}$ \\
\hline Wali & $28.77 \mathrm{a}$ & $27.87 \mathrm{a}$ & $0.90 \mathrm{a}$ & $96.93 \mathrm{a}$ \\
\hline Wortel & $21.83 \mathrm{~b}$ & $20.33 \mathrm{~b}$ & $1.50 \mathrm{a}$ & $93.13 \mathrm{a}$ \\
\hline Antin-3 & $15.23 \mathrm{c}$ & $10.50 \mathrm{c}$ & $4.73 \mathrm{a}$ & $71.39 \mathrm{~b}$ \\
\hline Papua Solossa & $20.60 \mathrm{bc}$ & $17.63 \mathrm{~b}$ & $2.97 \mathrm{a}$ & $85.80 \mathrm{a}$ \\
\hline $\mathrm{CV}(\%)$ & 15.13 & 16.73 & 60.87 & 8.44 \\
\hline
\end{tabular}

Data at the same column followed by the same characters are not significantly different according to DNMRT 5.0\%. 
The number of storage roots per $6 \mathrm{~m}^{2}$, nonmarketable storage roots per $6 \mathrm{~m}^{2}$, and percentage of non-marketable storage roots based on its number of the eight sweet potato local cultivars of West Sumatra and two national varieties were not significantly different. Moreover, data in Table 6 showed that weight of storage roots and marketable storage roots per $6 \mathrm{~m}^{2}$ of Rajo Langik and Wali local cultivars were significantly higher than other cultivars and two national checked varieties. Weight of storage roots and marketable storage roots per $6 \mathrm{~m}^{2}$ of all local cultivars were significantly higher than that of national checked varieties Antin-3.

\subsection{Organoleptic Values}

The sensory attributes related to organoleptic values of the storage roots of sweet potato cultivars evaluated were appearance, flavour, color, texture, and sweetness of the flesh of boiled storage roots by using the scales. The results were recorded in the forms where each taster can write down the number of the sample evaluated and an opinion about the consistency, color, texture, and sweetness of the boiled sweet potato storage roots. These forms had the codes used for each one of the descriptors.

Table 7 The hedonic scales of cosumers' sensory attributes to boiled storage roots of eight local cultivars of West Sumatra and two improved varieties of sweet potato in Indonesia.

\begin{tabular}{|l|c|c|c|c|c|l|}
\hline \multicolumn{1}{|c|}{ Cultivars/Varieties } & $\begin{array}{c}\text { Appear- } \\
\text { ance }\end{array}$ & Flavour & Texture & Color & $\begin{array}{c}\text { Sweet- } \\
\text { ness }\end{array}$ & Means \\
\hline Bogor & 2.27 & 2.27 & 2.13 & 2.53 & 3.00 & $2.44 \mathrm{c}$ \\
\hline Daus & 3.93 & 4.07 & 4.07 & 3.93 & 4.27 & $4.05 \mathrm{a}$ \\
\hline Hitam Pucuk Panyalaian & 3.33 & 3.60 & 3.33 & 3.73 & 2.40 & $3.28 \mathrm{ab}$ \\
\hline Pono & 3.20 & 3.60 & 3.13 & 3.27 & 3.87 & $3.41 \mathrm{ab}$ \\
\hline Rajo Langik & 3.33 & 3.07 & 2.87 & 3.73 & 4.00 & $3.40 \mathrm{ab}$ \\
\hline Roti & 3.33 & 3.00 & 3.13 & 3.07 & 2.67 & $3.04 \mathrm{bc}$ \\
\hline Wali & 3.40 & 3.60 & 3.07 & 3.60 & 2.07 & $3.15 \mathrm{bc}$ \\
\hline Wortel & 3.67 & 3.40 & 3.40 & 4.00 & 1.87 & $3.27 \mathrm{~b}$ \\
\hline Antin-3 & 2.93 & 3.33 & 3.07 & 3.67 & 2.27 & $3.05 \mathrm{bc}$ \\
\hline Papua Solossa & 3.73 & 3.67 & 3.53 & 3.33 & 1.20 & $3.09 \mathrm{bc}$ \\
\hline
\end{tabular}

Means followed by the same characters are not significantly different according to DNMRT 5.0\%.

Meaning of scales: $5=$ like extremely, 4=like moderately, 3=neither like nor dislike, $2=$ dislike moderately, and $1=$ dislike extremely.

Table 7 presents the scores for the sensory attributes of boiled storage roots of eight sweet potato local cultivars of West Sumatra province, Indonesia tested and two checked national improved varieties. The average scores for the sensory attributes of Daus and Rajo Langik local cultivars were 4.05 and 4.00, respectively. These were evaluated as moderately like by the consumers. The average score for the sensory attributes of local variety Daus is not significantly different from the average scores of local cultivars Hitam Pucuk Panyalaian, Pono, and Rajo Langik. It means that these four local cultivars were evaluated as moderately like by the consumers. Based on its scores for organoleptic values, these four local cultivars are potential for increasing the sweet potato marketing in West Sumatra province, Indonesia.

\section{CONCLUSION}

The study has explored eight local cultivars of sweet potato in West Sumatra, Indonesia. These local cultivars has been identified its growth, leaves, and storage roots characteristics. All local cultivars explored has also been evaluated its yield potentials and organoleptic values compared to two national checked varieties.

All sweet potato local cultivars in West Sumatra evaluated in this research are potential to become new introduced varieties in Indonesia, because it has capability to produced storage roots significantly higher than the average national sweet potato production in Indonesia. Four promising local cultivars for high productivity are Rajo Langik, Wali, Wortel, and Pono. Four local cultivars which is named Daus, Hitam Pucuk Panyalaian, Pono, Rajo Langik have good scores of organoleptic values, therefore these are potential for increasing the sweet potato marketing in West Sumatra, Indonesia. This study recommends the successive researches using sweet potato local cultivars Rajo Langik, Wali, Wortel, Hitam Pucuk Panyalaian, Pono, and Daus as the parent materials in sweet potato breedings in order to find out new high yielding and consumers' acceptable varieties. 


\section{ACKNOWLEDGMENT}

This work was supported by the Agricultural Research Management Project (ARMP) of the Indonesian Agency for Agricultural Research and Development (IAARD). We are gratefull to the ARMP personnel and IAARD decision makers for financial support. We sincerely acknowledge the contribution of the technician and agricultural extensionists for their help in the filed observations. We also appreciate the insightful comments of anonymous reviewers.

\section{REFERENCES}

[1] A. Badiane, P.M.D.D. Sylla, A. Diouf, L. Tall, M.S. Mbaye, N.S. Cissé, N.I. Dossou, S. Wade, and P. Donnen, Sensory evaluation and consumer acceptability of orange-fleshed sweet potato by lactating women and their children $(<2$ years old $)$ in Kaffrine, Central Groundnut Basin, Senegal, African Journal of Food Science 12(11) (2018) 288-296. DOI: $10.5897 / A J F S 2018.1730$.

[2] A. Mfewou, F.D. Engwali, P. Tchofo, Geography of the production of Ipomoea batatas (sweet potato): An analysis in the space of Santchou (West-Cameroon), SSRG International Journal of Humanities and Social Science (SSRG -IJHSS) 6(2) (2019) 67-72. http://www.internationaljournalssrg.org

[3] A.S.A. El Gendy and S.A. Khalik, Improving local varieties of sweet potato by simple recurrent selection, Middle East J. Agric. Res., 3(3) (2014) 511-516.

[4] C. Fonseca, J.P. Molina, and E.E. Carey, 1999, Farmer participation in the selection of new sweet potato varieties. In: Huaman (Ed.), Sweet Potato Germplasm Management (Ipomoea batatas): Training manual. International Potato Center. pp. 147-168.

[5] C. Wariboko and I. A. Ogidi, Evaluation of the performance of improved sweet potato (Ipomoea batatas L. LAM) varieties in Bayelsa State, Nigeria, African Journal of Environmental Science and Technology 8(1) (2014) 48-53. DOI: 10.5897/AJEST 2013. 1572

[6] E. Salim, Save Indonesia local variety, Info PVT \& PP 14(3) (2018), Plant Variety Protection and Agriculture Permits Gazette, the Indonesian Ministry of Agriculture.

[7] F. Kosmowski, A. Aragaw, A. Kilian, A. Ambel, J. Ilukor, B. Yigezu, J. Stevenson, Varietal identification in household surveys: Results from three household-based methods against the benchmark of DNA fingerprinting in Southern
Ethiopia, Cambridge University Press 2018 https://doi.org/10.1017/ S0014479718000030

[8] F. Rodriguez, 1999, Methods to evaluate culinary quality and other attributes for processing sweet potato storage roots. In: Huaman (Ed.), Sweet Potato Germplasm Management (Ipomoea batatas): Training manual. International Potato Center. pp. 189-206.

[9] G.D. Prain, I.G. Mok, T. Sawor, P. Chadikun, E. Atmodjo, and E.R. Situmorang, 1999, Interdisciplinary collection of Ipomoea batatas germplasm and associated indigenous knowledge in Anggi, Irian Jaya, Indonesia: The approach, the methods and the problems. In: Huaman (Ed.), Sweet Potato Germplasm Management (Ipomoea batatas): Training manual. International Potato Center. pp. 5777.

[10] I.G. Mok and P. Schmiediche. 1998. Collecting, Characterizing, and Maintaining Sweet Potato Germplasm in Indonesia. International Potato Center (CIP), ESEAP Regional Office, Bogor, Indonesia.

[11] ILETRI, Description of Sweet Potato's Popular Varieties 1977-2016. Indonesian Legumes and Tuber Crops Research Institute, Agency for Agricultural Research and Development, 2017.

[12] ILETRI, 2020, The variability of genetic resources of the collected sweet potato germplams in ILETRI: Technological information. Indonesian Legumes and Tuber Crops Research Institute, Agency for Agricultural Research and Development.

[13] J.A. Woolfe, Sweet potato, an untapped food resource, Cambridge University Press, Cambridge. 1992, 643p. [Google Scholar]

[14] J.N. Oggema, M.G. Kinyua, J.P. Ouma, and J.O. Owuoche, Agronomic performance of locally adapted sweet potato (Ipomoea batatas (L) Lam.) cultivars derived from tissue culture regenerated plants, African Journal of Biotechnology Vol. 6 (12) (2007)

1418-1425. http://www.academicjournals.org/AJB.

[15] M. Jusuf, St.A. Rahayuningsih, and Minantiyorini, Present status of sweet potato germplasm conservation in Indonesia. In R. Rao and $\mathrm{M}$. Hermann (editors), Conservation and Utilization of Sweet Potato Genetic Diversity in Asia Proceedings of the Asian Network for Sweet Potato Genetic Resources Workshop, 3-5 November 1999, Bogor, Indonesia. International Plant Genetic Resources Institute, 2001.

[16] M.J. Yakub, D. Harnowo, E. Ginting, Minantyorini, I.M.J. Mejaya, Haryono, Genetic diversity of local cultivars and improved varieties of sweet potato in 
Indonesia, 4th International Conference on Biodiversity, June 15-17, 2015, Las Vegas, USA, J Ecosys Ecograph 2015, 4:3. http://dx.doi.org/10.4172/ 2157-7625.S1.020

[17] M. Tanaka, K. Ishiguro, T. Oki, and S. Okuno, Functional components in sweet potato and their genetic improvement. Breed Sci. 67(1) (2017) 52-61. DOI: $10.1270 /$ jsbbs. 16125

[18] P.P. Leksrisompong, M.E. Whitson, V.D. Truong, and M.A. Drake, Sensory attributes and consumer acceptance of sweet potato cultivars with varying fleshcolors, Journal of Sensory Studies 27 (2012) 5969. DOI: 10.1111/j.1745-459X.2011. 00367.x.

[19] P.R. Kamalkumaran and T. Arumugam. 2017. Evaluation of sweet potato germplasm accessions for high tuber yield and carotene content, Journal of Root Crops 43 (1) (2017) 15-22. Indian Society for Root Crops, India.

[20] R. Dewi, S.D. Utomo, M. Kamal, P.B. Timotiwu, S. Nurdjanah, Genetic and phenotypic diversity, heritability, and correlation between the quantitative characters on 30 sweet potato germplasms in Lampung, Indonesia, Biodiversitas 20(2) (2019) 380386. DOI: $10.13057 /$ biodiv/d200211.

[21] R. Suryani, 2016, Outlook of Food Crops Commodities: Sweet potato. Central of Agricultural Data and Information Sistem, Ministry of Agriculture. 87p. (Indonesian)

[22] S. Laurie, F. Calitz, M. Mtileni, W. Mphela, S. Tjale, Performance of informal market sweet potato cultivars in on-farm trials in South Africa, Open Agriculture $2017 \quad$ (2) 431-441. https://doi.org/10.1515/ opag-2017-0047.
[23] S.L. Rahmannisa, B. Waluyo, and A. Karuniawan, Genetic parameter performance of local cultivars of sweet potato from Cilembu, West Java, Seminar Proceeding on Legumes and Tuber Crops Research Results 2011, 675-684.

[24] S.M. Laurie, F.J. Calitz, P.O. Adebola, A. Lezar, Characterization and evaluation of South African sweet potato (Ipomoea batatas (L.) LAM) land races, South African Journal of Botany 85 (2013) 10-16. http://dx.doi.org/10.1016/j.sajb.2012.11.004.

[25] S. Samiyarsih, N. Fitrianto, E. Azizah, W. Herawati, Rochmatino, Anatomical profile and genetic variability of sweet potato (Ipomoea batatas) cultivars in Banyumas, Central Java, based on RAPD markers, Biodiversitas 21(4) (2020) 1755-1766. DOI: $10.13057 /$ biodiv/d210460

[26] Y. Belay, A review on sweet potato breeding for quality traits, International Journal of Entomology and Nematology Research 2(1) (2018) 25-34. www. eajournals.org

[27] Z. Huaman, 1999a, Systematic botany and morphology of the sweet potato plant. In: Huaman (Ed.), Sweet Potato Germplasm Management (Ipomoea batatas): Training manual. International Potato Center. pp. 1-16.

[28] Z. Huaman, 1999b, Morphologic identification of duplicates in collections of Ipomoea batatas. In: Huaman (Ed.), Sweet Potato Germplasm Management (Ipomoea batatas): Training manual. International Potato Center. pp. 28-56. 